регламентирующих участие потерпевшего в уголовном судопроизводстве" Пленум указывает о возможности признания отдельных групп несовершеннолетних гражданскими истцами, при этом ссылаясь на положения ст.37 ГПК РФ, согласно которой указанные лица вправе лично защищать свои права, свободы и законные интересы.

Использование аналогии в уголовном процессе предоставляет безусловные преимущества правоприменителю в деятельности по устранению противоречий в тех ситуациях, которые требуют, но не имеют нормативного регулирования.

В частности, невозможно переоценить значимость использования аналогии закона при рассмотрении конкретных уголовных дел, например при проведении судебных действий, производство которых в настоящее время не регулируется УПК РФ.

Одновременно с этим использование уголовно-процессуальной аналогии при вынесении судебных решений дает толчок нормотворчеству, обогащая судебную практику новыми правоположениями и концентрировано указывая на недостатки уголовнопроцессуального законодательства, определяя направления его дальнейшего совершенствования.

$$
* * *
$$

1. Постановление Конституционного Суда РФ от 02.07.1998 N 20-П "По делу о проверке конституционности отдельных положений статей 331 и 464 Уголовно - процессуального кодекса РСФСР в связи с жалобами ряда граждан"// СПС КонсультантПлюс [Электронный ресурс]. URL: http://www.consultant.ru/ (дата обращения: 19.11.2021).

2. Постановление Пленума Верховного Суда Российской Федерации от 29 июня 2010 г. N 17 «О практике применения судами норм, регламентирующих участие потерпевшего в уголовном судопроизводстве»; Постановление Пленума Верховного Суда РФ от 10 февраля 2009 г. N 1 (ред. от 29.11.2016) "О практике рассмотрения судами жалоб в порядке ст.125 УПК РФ" // СПС КонсультантПлюс [Электронный ресурс]. URL: http://www.consultant.ru/ (дата обращения: 19.11.2021).

3. Ким, С. С. Проверка показаний на месте в стадии судебного следствия как особое средство уголовнопроцессуального познания // Учёные записки КнАГТУ. Комсомольск-на-Амуре, 2014. №3. С.77-82.

4. Белкин, А. Р. Несовершенство процессуальной регламентации отдельных следственных действий и попытки оптимизации комплекса методических и тактических средств расследования преступлений // Вестник Нижегородской академии МВД России. Нижний Новгород. 2016. № 4 (36). С. 57-63.

\title{
Кирюшин И.И., Старченко П.Р. \\ Технические средства фиксации административных правонарушений в области безопасности дорожного движения: проблемные аспекты
}

Барнаульский юридический институт МВД России

(Россия, Барнаул)

doi: 10.18411/trnio-12-2021-173

\section{Аннотация}

В статье раскрыты положительный опыт использование видеокамер для снижения уровня латентности правонарушений в области безопасности дорожного движения, а также на перспективу следующая мера оснастить все автомобили «черными ящиками» записывающими и передающими данные о движении и состоянии транспортного средства в режиме реального времени.

Ключевые слова: Федеральной информационной системы ГИБДД, безопасности дорожного движения, черными ящиками, цифровые технологии, сотрудник полиции, центра автоматической фиксации административных правонарушений.

\section{Abstract}

The article reveals the stages of the formation of professional competencies among students in educational institutions of the system of the Ministry of Internal Affairs of Russia by means of 
digital educational technologies, using the electronic information and educational environment (EIOS) of the Ministry of Internal Affairs of Russia and the problems of their solution.

Keywords: competencies, digital technologies, police officer, professional development, professional activity, electronic information and educational environment.

Федеральным законом от 7 февраля 2011 года № 3-Ф3 «О полиции» (далее - Ф3 «О полиции») закреплена обязанность полиции использовать в своей деятельности достижения науки и техники. Это положение объясняется высоким уровнем цифровизации общества и объективной необходимостью соответствия полиции данному уровню.

Также в Ф3 «О полиции» указано, что полиция использует технические средства для фиксации обстоятельств совершения преступлений, административных правонарушений, обстоятельств происшествий, в том числе в общественных местах, а также действий сотрудников полиции, выполняющих возложенные на них обязанности. Использование специальных технических средства (далее - СТС) для надзора за дорожным движением, в частности работающих в автоматическом режиме специальных технических средств, имеющих функции фото- и видеозаписи, уже не ново в наши дни. В своем исследование и мы будем говорить о работающих в автоматическом режиме видеокамерах, осуществляющих надзор за дорожным движением.

В ведении государственной инспекции безопасности дорожного движения находятся только стационарные комплексы видеофиксации нарушений ПДД, которые устанавливает Центр безопасности движения РФ. Сама Госавтоинспекция установкой видеокамер не занимается - их монтаж и обслуживание находится в ведении региональных администраций.

В Алтайском крае работа данных камер на федеральных трассах находится в ведении организации «Дорнадзор», которая занимается установкой и обслуживанием объектов, она же извлекает из видеокамеры флэш-накопитель с записанной на нем информацией и копирует её. После чего информация подвергается осмотру инспектором Центра автоматической фиксации административных правонарушений (далее - ЦАФАП) или же подвергается автоматической отработке (инспектор впоследствии всё равно должен будет ее перепроверить).

Однако уже здесь появляются некоторые проблемные аспекты. Так, обращаясь к судебной практике, нами был обнаружен весьма интересный случай: гражданину вынесен штраф за превышение скоростного режима, данное нарушение было зафиксировано работающей в автоматическом режиме видеокамерой, но транспортное средство гражданина, в это время двигалась не по дороге, а стояла на платформе эвакуатора, который осуществлял движение с нарушением ПДД. Этот прецедент имел место быть вследствие невнимательности инспектора, осуществляющего осмотр поступающей с видеокамер информации.

Несмотря на подобные случаи, использование видеокамер - это реальная возможность снижения уровня латентности правонарушений в области безопасности дорожного движения (далее - БДД). Это положение объясняется тем, что сотрудники полиции в силу объективных обстоятельств не могут находиться на всех участках автодорог одновременно, в отличие от видеокамер, установка которых возможна повсеместно. При применении видеокамер в надзоре за дорожным движением исключается и принцип субъективизма при выявлении и регистрации правонарушений. Это объясняется тем, что сотрудник полиции прежде всего человек, на которого как на любого другого может оказываться моральное и иное психологическое воздействие, не редки случаи, когда правонарушители уговаривают сотрудника «не наказывать», чего не сделаешь с видеокамерой. Этот же фактор исключает возможность образования конфликтной ситуации между правонарушителем и сотрудником. Всё это в совокупности обеспечивает реализацию принципа неотвратимости наказания за правонарушения на автодорогах [1].

Однако сотрудник полиции незаменим при надзоре за дорожным движением, что определяется достаточным количеством проблемных аспектов в использовании СТС при 
обеспечении БДД. Так, в регионах, соседствующих с иностранными государствами, дорожное движение осуществляют водители с иностранными государственными регистрационными номерами. При совершении правонарушения такими водителями, последние остаются безнаказанными. Это объясняется тем, что система автоматической фиксации хотя и легко может опознать регистрационный номер с любым буквенноцифровым обозначением (если, конечно, на нем нет специальной ленты светоотражателя, откидной рамки, магнита или попросту грязи, что пресечь может только сотрудник полиции), но для того, чтобы привлечь водителя-иностранца к ответственности необходимо определить владельца этого номера, что становится невозможно так как в базе данных нашего государства не содержит информации иностранного государства [4]. Наказать собственника, проживающего за границей проблематично. К тому же у Федеральной таможенной службы, за информацией о правонарушителе к которой мог бы обратиться сотрудник полиции, нет данных об автомобилях, зарегистрированных в странах ЕАЭС, — в Белоруссии, Армении, Киргизии и Казахстане.

Данная проблема может быть разрешена посредствам осуществления следующих мер: все транспортные средства, въезжающие на территорию Российской Федерации в обязательном порядке должны проходить процедуру внесения сведений о них и их собственниках в базу данных Федеральной информационной системы ГИБдД (далее - ФИС ГИБДД М), что позволит сотрудникам полиции осуществлять быструю обработку, распределение, хранение и удобный обмен данными об исследуемых объектах учета внутри системы. В таком случае, по выезду данных транспортных средств, при помощи упомянутой ранее базы данных ФИС ГИБДД М, становится возможным проверять эти транспортные средства и их водителей на наличие фактов нарушения ПДД и непогашенных штрафов. В этом случае появляется возможность наложения санкций в отношении правонарушителей в рамках Кодекса Российской Федерации об административных правонарушениях (далее КоАП РФ).

Так же следует упомянуть, что практике известны случаи, когда право собственности на транспортное средство оформляется на несовершеннолетнее лицо. Согласно Российскому законодательству ребенок может быть собственником любого имущества. Теперь обратимся к ст. 2.3 КоАП РФ - лицо, не достигшее шестнадцатилетнего возраста, не подлежит ответственности. Согласно ст. 2.6.1 КОАП РФ в случае фиксации административного правонарушения с помощью специальных технических средств, работающих в автоматическом режиме, к ответственности привлекается собственник транспортного средства. Следовательно, согласно букве закона, нет состава административного правонарушения так как нет виновного в нем лица [3].

В рамках рассмотрения заявленной темы следует обратиться к существующей в Алтайском крае практике по надзору за дорожным движением с помощью беспилотных летательных аппаратов. Это направление видится перспективным в том, что на беспилотных летательных аппаратах (далее - БЛА) возможно размещение камер фото- видеофиксации правонарушений, работающих в автоматическом режиме. Но и здесь просматриваются положительные и отрицательные моменты. Так, к положительным мы относим: во-первых, возможность работы на большой высоте, что делает БЛА незаметным для правонарушителей, следствием чего создается необходимость постоянного соблюдения ПДД, во-вторых, возможность БЛА сопровождать транспортное средство, что может быть использовано как для нужд административного производства, так и для оперативнопоисковых мероприятий. К минусам работы данного направления относятся следующие факторы: во-первых, это проблема осуществления контроля скоростного режима, в то время как это правонарушение одно из самых распространенных в области нарушений ПДД, вовторых, отсутствие возможности съемки государственного номера в той плоскости, в который обычно осуществляет полёт БЛА, в-третьих, следует учесть тот факт, что работа 
данного направления в настоящее время ведется лишь по фактам пересечения сплошной линии разметки или выезда на встречную полосу движения, что само собой не покрывает всё разнообразие правонарушений ПДД.

С автомобилизаций и цифровизаций общества развиваются и способы «обхода» законодательства. Разного рода ухищрения, используемые водителями транспортных средств, свидетельствуют о том, что необходима разработка более совершенных специальных технических средств фиксации административных правонарушений в области безопасности дорожного движения [2].

Помимо указанных нами ранее возможных путей решения некоторых существующих на данный момент проблемных аспектов контроля и надзора за дорожным движением предлагается на перспективу следующая мера оснастить все автомобили «черными ящиками» - специальными устройствами, записывающими и передающими данные о движении и состоянии транспортного средства, с указанием на то, что в будущем эксплуатация транспортного средства без такой системы будет запрещена. В рамках обеспечения БДД данная система позволила бы контролировать местоположение транспортного средства на дорожном полотне, скорость движения и иные показатели состояния автомобиля. Камеры видеонаблюдения, работающие в стационарном режиме это, однозначно, благоприятно влияющие на состояние БДД объекты, однако создаются более «умные» системы, которые правоохранительные органы, непременно, должны использовать в целях обеспечения безопасности граждан.

$$
* * *
$$

1. Дымберов А.Д. Административно-правовые аспекты организации деятельности по использованию специальных технических средств автоматической фиксации правонарушений при надзоре за дорожным движением // Административное право и процесс. - 2018. - № 1. - С. 45-48.

2. Иванов И.П., Осинцева Л.М., Кирюшин И.И. Факторы, влияющие на обеспечение безопасности дорожного движения // В сборнике: Проблемы информационного обеспечения деятельности правоохранительных органов. сборник статей 7-й Всероссийской научно-практической конференции. Редакционная коллегия: Амельчаков И.Ф., Озеров И.Н., Акапьев В.Л., Прокопенко А.Н., Насонова В.А., 2020. С. 90-95.

3. Иккерт А.В. К вопросу о современном состоянии законодательства в сфере использования технических средств фиксации административных правонарушений в области дорожного движения // Актуальные вопросы юридической науки. - 2019. - № 4 (4). - С. 33-40.

4. Как скрыть номер от камер видеофиксации. URL: https://otkidnye-ramki.com/blog/kak-skryt-nomer-ot-kamer/ (Дата обращения: 23.10.2021)

5. Черный ящик в авто?! https://www.drive2.ru/c/4585425293447709138/ (Дата обращения: 23.10.2021)

Клочкова И.Д.

История развития института банкротства в России

ФГБОУ ВО «Елеиякий государственный университет им. И.А. Бунина»

(Россия, Елеи)

doi: 10.18411/trnio-12-2021-174

Научный руководитель: Ёркина Т.Н.

\section{Аннотация}

В статье анализируются основные этапы развития института банкротства нашего государства. Устанавливается логическая последовательность между этапами, которая определяется усложнением рыночных отношений, с одномоментным улучшением нормативно-правовой базы. Также автор выделяет основные направления совершенствования действующего законодательства.

Ключевые слова: несостоятельность, должник, процедура банкротства, торговля, история развития процедур банкротства. 